\section{日本街区保全型社区营造的发展与实践 \\ DEVELOPMENT AND PRACTICES OF \\ NEIGHBORHOOD CONSERVATION-BASED \\ COMMUNITY BUILDING IN JAPAN}

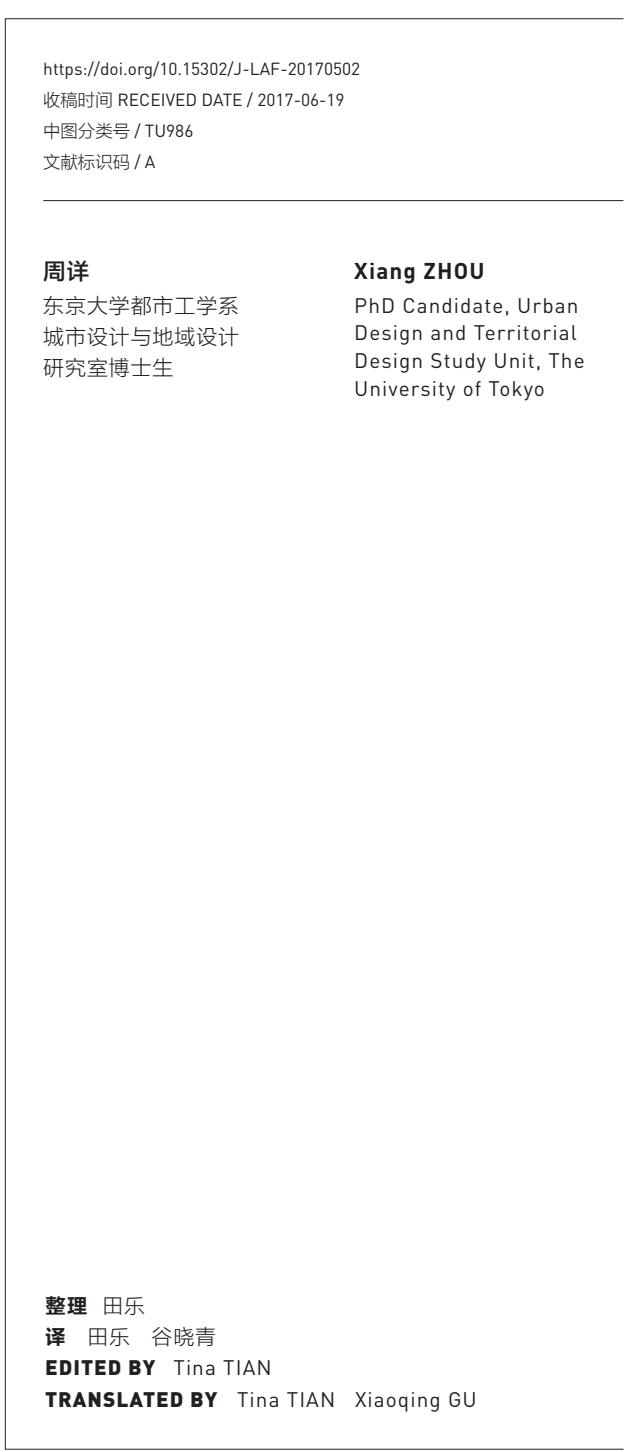

摘要

社区营造强调从社会、政治和文化的角度理解街区的价 值。街区保全型社区营造作为其中一种主要的营造方式, 是日 本历史街区保护从静态保存向动态保全转变过程中的创举。文 章首先从日本历史风貌保护制度的流变入手, 讨论日本历史环 境的保护对象从单体到全域的演进过程, 以及街区保全型社 区营造产生的方式。其次, 文章以八女市福岛地区为例研究公 众参与街区保全型社区营造的途径, 旨在发掘街区保全视角下 日本社区营造对中国当代历史街区保护和开发的启示意义。最 后, 文章认为强调公众参与和地方赋权, 鼓励和推动民间团体 的介入是当前语境下中国历史街区实现物质和文化的保护与再 生的应由之路。

\section{关键词}

历史街区; 街区保全制度; 公众参与; 街区保全型社区营造

\begin{abstract}
Community building aims to emphasize and celebrate social, political, and cultural value of neighborhoods. As a major way in the neighborhood conservation in Japan, neighborhood conservation-based community building was generated in the process of historic neighborhood protection developing from static preservation to dynamic conservation. Starting with a review on the history of the protection system of traditional quality in Japan, this paper puts its focus on the evolution of the protected targets - from only single objects to whole communities - and the approaches applied in the neighborhood conservation-based community building. Taking the empowerment and public engagement of neighborhood conservation in Fukushima, Yame as a case study, this paper studies and reveals the significance that provides reference to the development and protection of the historic neighborhoods in China. Finally, the paper argues that encouraging public engagement and motivation of civil organizations in the empowerment is crucial to the physical and cultural conservation and renewal of the historic neighborhood in the current social and political context of China.
\end{abstract}

\section{KEY WORDS}

Historic Neighborhood; Conservation System of Historic Neighborhood; Public Engagement; Neighborhood ConservationBased Community Building 


\section{1 街区保全型社区营造的内涵}

\section{1 “街区保存” 与 “街区保全” 的思辨}

在日本，历史街区保护领域经常涉及 “保存” 和“保全”这两个 概念。“街区保存”通常意指在尊重城市结构遗产价值的基础上, 采 用最低限度的补救措施来维护街区现状; 而 “街区保全” 则是指在尊 重历史城市空间结构的基础上延续原有机能, 并适当加人满足当代生 活需求的新内容和新功能, 使历史街区的特性得以改善和活用。学者 西村幸夫认为 ${ }^{[1]}$, 虽然以往关于历史街区的保护总是使用 “保存” 一 词, 但将 “保全”与 “街区”一词联立, 是为了使该词具有包容地域 社会进行新陈代谢的含义。因此, 相对于 “街区保存” 这一静态的保 护概念, “街区保全” 则强调让街区以原本的方式存在着, 并活用街 区的特性使之再生。学者间濑启允在翻译约翰 - 帕斯莫尔的经典论著 《人类对自然的责任》时, 也表达出类似的观点 ${ }^{[2]}$ : “保存” 强调人 类栖居环境价值本身; “保全” 则将人类生存的环境看作一种可以因 借的工具, 同时也是一种实现保护的途径。这种观点表明人类生活的 环境不再仅作为表示 “存在” 的静态概念被理解, 同时也开始作为表 示 “状态” 的动态理念被重新审视。由于街区内有居住者生活于此, 因此符合现代生活需求的新陈更替是必须的, 也是在所难免的, 关键 在于如何控制这些更替变化。在城市更新日益成为历史街区保护主要 趋势的今天, 我们需要调控的不是变化, 而是变化的速度和程度。由 此, 以维持地域社会健康生活为目标的街区保全型社区营造（日语： 町並み保全型まちづくり) 应运而生。

\section{2 社区营造的概念与传播}

日本的社区营造运动始于 20 世纪 60 年代, 经过 50 余年的发展, 已 经从历史街区的专项保护演变为综合性的社区营造。由于日本的社区 营造除了具有西方国家社区营造运动中普遍存在的政治层面和社会层 面的因素外, 更强调从文化的角度来理解日本传统空间意象保全的含

\section{Concept of Neighborhood Conservation-Based Community Building}

1.1 The Difference between Neighborhood Preservation and Neighborhood Conservation

Preservation and Conservation are two concepts usually involved when studying Japan's historic neighborhood protection. Generally, Neighborhood Preservation refers that only the minimum remedial measures are taken to maintain the original physical structure of a historic neighborhood. Neighborhood Conservation is to maintain the historic neighborhoods' original functions while integrating new services to meet the needs for modern life, so as to restore and celebrate the traditional quality of historic neighborhoods. Yukio Nishimura ${ }^{[1]}$, a Japanese scholar, argued that differing from Preservation which though had been widely used in Japan's historic neighborhood protection, the concept of Conservation is to highlight the importance of neighborhood renewal at a regional scale. Therefore, if we understand Preservation as a static approach to neighborhood protection, the concept of Conservation emphasizes that neighborhoods should maintain its original lifestyle and be revitalized by dynamically celebrating its local identity. Mase Hiromasa expressed a similar idea when he was translating the work Man's Responsibility for Nature by John Passmore ${ }^{[2]}$. He stated that the concept of Preservation underscores the value of human habitat itself, while the concept of Conservation taking the environment where human live in as the instrument which can be utilized to achieve the protection in return. The latter suggested that the environment for human living can be no longer understood as a static existence; it should be examined as a dynamic concept representing one's state. Neighborhood renewal is necessary and inevitable to meet the needs of citizens' modern lives who live in the historic neighborhoods. What matters is how to manage the replacement and changes, especially in the current context that city renewal increasingly becomes the major trend in historic neighborhood protection, and what we need to manage is how quick and far it changes. With an aim at maintaining the healthy lifestyle of local communities, neighborhood conservationbased community building (町並み保全型まちづくり in Japanese) came into being.

\subsection{Development of the Concept of Community Building}

The community building movement in Japan started since the 1960s, evolving from single protection act for certain historic neighborhoods towards comprehensive community building. Unlike that in Western countries, community building in Japan not only has been influenced by political and social factors, but 
义，因此产生街区保全型社区营造这一概念。由于西方学者很难将日 本社区营造的哲学内涵用诸如 “Community Building” 这样的词汇进行 概括，西方学界逐渐接受用Machizukuri（日语まちづくり的发音）一 词来表征日本社区营造的全部内涵。2017年，学者佐藤滋在其著作中 为日本的社区营造作出定义 ${ }^{[3]}$ : 所谓的社区营造就是以地域社会的现 有资源为基础, 展开多样化的协作, 使周边居住环境逐渐改善, 进而 提升社区活力的一系列持续的活动。基于此, 街区保全型社区营造的 概念则可以表述为：善用街区遗留下来的历史文化资源和空间结构特 征, 谋求地域社会的活化与再生的综合性社区营造运动。从这种意义 上讲，街区保全型社区营造的目标并非创造某种全新的东西，而是仔 细玩磨现有事物, 以使之脱胎换骨。因此, 街区保全型社区营造是一 种对物质环境和社会环境进行双重营造的方式。

20 世纪90年代, 台湾学者将社区营造的概念引人台湾, 并在岛内 开展了实验性的社区营造运动 ${ }^{[4]}$ 。近年来这一理念渐为中国大陆学界 所接受，掀起了具有中国大陆特色的社区营造运动。由于街区保全型 社区营造中街区的概念已经突破历史街区的范畴，转向综合性社区营 造, 因此, 重新审视日本的社区营造运动, 特别是与时代并进的街区 保全型社区营造的诞生历程，无疑对处于社区营造初级阶段的中国实 践具有启示意义。

\section{2 日本历史风貌保护制度的流变与街区保全型社区营造的诞生}

\section{1 早期保护制度的创立}

日本第一代保护制度的创立始于 1868 年明治维新以后，由于国内 欧化主义和旧物破坏主义日益盛行，文化遗产的保护与延续面临严重 的危机。在这种背景下, 《古器旧物保存方》作为日本首个关于文化 财 (日本对文化遗产的称谓) 保护的措施而颁布。1895年甲午战争结 束以后，日本国内的民族意识空前高涨。随后，作为日本首次将建造 also has emphasized the cultural significance and integrity of the conservation of traditional Japanese buildings and structures, where Machizukuri (まちづくり in Japanese), the concept of neighborhood conservation-based community building was generated. Notably, it is hard to express the original philosophical meaning of Machizukuri by simply translating it as Community Building, therefore Machizukuri now is also adopted by West scholars in their study on Japanese community building. In his latest work published in 2017, Sato Shigeru defined Community Building as a series of continuous activities done to improve the living environment and to invigorate neighborhoods by utilizing available resources in local society with various coordination ${ }^{[3]}$. Stemmed from this view, the concept of Neighborhood Conservation-Based Community Building can be defined as a comprehensive community building movement with an aim at revitalizing and regenerating local society by utilizing and celebrating the historical and cultural resources and traditional buildings. That means the goal of neighborhood conservationbased community building is to make the historic neighborhood carefully remoulded, rather than completely created, to both the material and social environment.

The concept of Community Building was introduced to Taiwan in the 1990 s, leading to an experimental movement ${ }^{[4]}$. In recent years, the concept has been introduced to the mainland of China, where many related practices emerged. Neighborhood conservation has developed beyond historic neighborhood protection towards comprehensive community building. Learning from the Japanese experience, especially through a profound review on the history of the emergence and development of community building, would help enlighten the unformed practice of community building in China.

\section{The Development of Protection System of Traditional Quality and the Emergence of Neighborhood Conservation- Based Community Building in Japan}

\subsection{Early Protection Acts}

Japan's protection system was first established after the Meiji Reform since 1868. Afflicted by the europeanism and heritage vandalism in Japan at that time, the preservation and protection of cultural heritage were greatly impacted. Under this background, Edict for the Preservation of Cultural Relics, the first act on the protection of historic cultural properties, was issued in Japan. After the First Sino-Japanese War in 1895, influenced by a nationwide ambitious patriotism, the Japanese government introduced the Law for the Preservation of Ancient Shrines and Temples, which first included historic buildings and structures as 
物列为保护对象的《古社寺保存法》颁布, 其中由国家对保护对象进 行指定的制度显现出日本现行文化财保护制度的维形 ${ }^{[5]}$, 日本建造物的 保护历史就此拉开帷幕。随着都市的建设, 日本国内的其他史迹和天 然纪念物 (由动植物、自然地貌等构成的自然遗产) 由于缺乏相应法 规保护而陆续遭到破坏。在这种情况下, 《史迹名胜天然纪念物保存 法》于1919年颁布。该制度规定, 对于没有被指定为保护对象的建造 物, 若其位于指定的史迹或名胜之内, 则将其视为重要的构成要素进 行保护。

昭和初年, 日本文物和重要艺术品流失海外的事件屡有发生。日 本遂于1929年制定了《国宝保存法》，该法扩大了保护对象的范围， 将地方以及个人所有物纳人其中。鉴于国宝鉴定作业耗时较长, 为防 止未被鉴定的重要美术品流失海外, 日本于1933年以临时立法的形式 制定了《重要美术品保存法律》 ${ }^{[6]}$ 。由此可见, 早期保护制度的设立更 多是在紧急情况下的被动应对。

\section{2 战后保护制度的积极拓展}

相较于之前的被动应对, 第二次世界大战后, 日本政府以主动 的姿态对《史迹名胜天然纪念物保存法》《国宝保存法》《重要美术 品保存法律》这三项法规进行了整合, 并于1950年颁布《文化财保护 法》, 形成了延续至今的历史风貌保护制度 ${ }^{[5]}$ 。日本政府又先后于 1954 年和1968年对该法进行了两次修订, 以因应时代的发展需求。然而随 着日本经济的腾飞, 席卷全国的城镇化进程造成了自然环境与历史风 貌的双重破坏。日本政府随即于1966年制定了《古都保存法》。该法 将历史建造物及能够展现古都风貌及土地利用情况的周边环境定义为 “历史风土” , 并将具有保护意义的地区指定为 “历史风土保存区 域”。其中特别重要的区域可划定为城市规划土地利用分区中的 “历 史风土特别保存地区” [7]。因此, 《古都保存法》的颁布使日本历史风 貌的保护从 “点的保存” 拓展为 “面的保全” , 并达到与城市规划制 度相整合的效果。但是, 该法仅保护了那些曾经作为日本首都的城市 (京都、奈良、镰仓等)。这种典型的重点保护方式在有选择地保护 重点区域的同时, 却导致其他地方文化遗产遭受忽视和破坏。此外, 由于将民宅划定为保存地区会给日后执行规范带来诸多困扰，因而大 protected objects. This act can be considered as a beginning and an embryonic form of the national protection system of cultural properties in Japan ${ }^{[5]}$. However, other historic man-made heritages, as well as natural heritages (including fauna and flora habitats, and scenic landforms), were destroyed by aggressive urban construction. As a legal measure, the Law for the Historic Sites, Scenic Places, and Natural Heritages was introduced in 1919 , according to which all the structures located within a protected area should be protected, whether it was recognized as a protected target itself or not.

In early years of Showa, a lot of cultural relics and artist works were shipped overseas. The Law for the Protection of National Treasures, issued in 1929, further recognized the treasures owned by local governments and individuals as protected objects. However, the property identity process often took quite a long time. In 1933, the Japanese government released the Law for the Preservation of Important Fine Arts as a supplemental act against the overseas smuggling of unidentified important properties ${ }^{[6]}$. It is easily found that most of the early protection acts were introduced as passive responding measures to pressing events.

\subsection{The Development of Protection Institution after World War II}

After the World War II, through the combination of the Law for the Historic Sites, Scenic Places, and Natural Heritages, Law for the Protection of National Treasures, and Law for the Preservation of Important Fine Arts, Japanese government issued the Act on Protection of Cultural Properties in 1950, revised in 1954 and 1968, establishing a protection institution of heritages working until nowadays ${ }^{[5]}$. Along the economic growth, lots of natural heritages and traditional features were destroyed in the urbanization process. Then the Japanese government enacted the Ancient Capital Preservation Law in 1966, which recognized the historic buildings and their surroundings as Historic Area, and identified Specific Protection Areas. Furthermore, the areas with extremely high cultural value were designated as Special Preservation Areas in urban planning ${ }^{[7]}$. The introduction of the Ancient Capital Preservation Law led the protection of historic quality from preservation of individual buildings to comprehensive protection of a certain historic area, integrating with the urban planning system. However, the Law only covered cities which were designated as capitals ever, such as Tokyo, Nara and Kamakura. This selective protection initiative ignored the importance of the cultural heritages in other regions which were prone to be destroyed. Besides, extensive private residential areas with high historic significance were excluded from the protected inventory in the Law, resulting 
片具有保护价值、以民宅为特色的历史街区均被排除在指定范围之 外。这让人们不得不开始思考该法在广域保护上的有效性。

\section{3 街区保全型社区营造的兴起与传统建造物群保存制度的设立}

1970年以后, 日本城市中体量巨大的现代派建筑的出现破坏了传 统街区的历史风貌。在这种情况下, 基于地域历史风貌保护的社区营 造在日本各地开展起来。地方政府因应这种自发的保护需求陆续制定 地方保护条例, 并于1975年促成《文化财保护法》的第三次修订。该 修订法提出了传统建造物群保存制度（以下简称 “传建制度” ），即 将与周边环境融为一体、有助于形成历史风貌区的传统建造物集群列 为保护对象, 并将经市町村依据城市规划法或保存条例认定的上述区 域指定为 “传统建造物群保存地区”（以下简称 “传建地区” )。该 制度在街区保全型社区营造的推动下与城市规划制度整合, 最终将传 统历史街区和居民聚落纳人到 “面的保全” 体系中来。截至2017年 8 月, 日本已有 115 个地区 (约 $3883 \mathrm{hm}^{2}$ ) 被划定为重要传建地区 ${ }^{[8]}$ 。与由 国家 “自上而下”指定的其他文化财不同, 传建地区是市町村在与当 地居民对话协商之后, “自下而上” 进行的自主决定。这种在尊重产 权所有人意愿的前提下进行的保护工作成为日本保护制度的一大特点 ${ }^{[9]}$ 。 下文将通过具体案例对该特点进行详细探讨。

\section{4 从社区营造到全域保护的实现}

自1980年起, 日本历史风貌的保护已不仅着眼于文化财的保护, 而开始以市街地全域的景观维护和环境功能整备为目标, 旨在着重挖 掘城镇的总体魅力。1 983 年, 日本建设省制定了《都市景观形成示范 计划》, 提出以行政区全域为整治对象, 实施兼顾软硬件设施的综合 城市规划政策 ${ }^{[10]}$ 。1996年, 建设省又颁布了 《文化政策大纲》, 提出地 域营造和社区营造的基本方针, 强调中央政府和地方社会的联系与分 工，主张以地方分权作为社区营造的基点。同年，《文化财保护法》 进行第四次修订, 将近代建造物列入保护对象, 通过更为广泛的保护 措施来弥补之前强制指定制度的弊端。这标志着日本历史风貌的保护 from avoiding the problems and conflicts that might be brought by the law enforcement in the future. Thus, the Law's protection effectiveness was widely questioned.

\subsection{The Emergence of Neighborhood Conservation-Based Community Building and the Establishment of Protection Institution of Traditional Building Groups}

The massive construction of modern buildings ruined the traditional style of the historic neighborhoods in Japan after the 1970s, stimulating various community building movements based on the protection of historic neighborhood. To meet different protection commands, local governments began to make specific regulations and initiatives, together with the Act on Protection of Cultural Properties amended for the third time in 1975. In the Amendment, the traditional building groups which could be identified as a whole were recognized as protected targets and designated as Protection Areas of Traditional Building Group (PATBG) through urban planning laws and regulations by municipal governments. Promoted by the movement of neighborhood conservation-based community building, the PATBG protection institution began to integrate with urban planning system to facilitate the comprehensive conservation of historic neighborhood and traditional settlements. By the end of August 2017, 115 PATBGs (covering a total area of nearly $3,883 \mathrm{hm}^{2}$ ) were designated ${ }^{[8]}$. Differing from other cultural properties designated by state governments, PATBGs were identified by local governments and local residents - who were also the property owners based on common willingness and agreement ${ }^{[9]}$, which was key to this protection institution and would be elaborated through a case study.

\subsection{From Community Building to Overall Conservation}

Since the 1980s, the conservation of traditional quality in Japan had put focus from cultural property protection towards landscape maintenance and improvement at street, city, and regional scales to strengthen the local identity of cities and towns. In 1983, the Construction Ministry of Japan published the Demonstration Plan of Urban Landscape, according to which each administrative district was designated as a unit on landscape maintenance and improvement through an overall urban planning policy taking all material and cultural facilities into consideration ${ }^{[10]}$. Enacted in 1996 by the Construction Ministry, the Outlines of Cultural Policy was published to offer principles for regional identity making and community building, highlighting the connection and the duty of the central government and local communities, and claiming that empowerment was the basis of community building. In the 
已从单一、價化的保护走向多元、柔性的综合保护 ${ }^{[1]}$ 。20世纪 90 年代日 本泡沫经济破灭, 在全民反思浪潮的影响下, 保护工作确立了以循序 渐进的方式逐步推进城市建设的指导思想, 促进了城市建设与社区营 造走向以保全历史、文化和自然环境为目标的良性循环阶段。

2004年, 《文化财保护法》进行第五次修订, 将人与自然互动产 生的文化景观也列入保护范围 ${ }^{[12]}$ 。同年, 日本颁布《景观法》, 该法 适用于所有城镇和乡村, 以保护美好的国土风貌、创造多样化的生活 环境以及富有个性的地方社会为目标。该法案的出台使地方政府自主 建立的景观制度有了明确的法律依据, 社区营造也可以以此为保障, 演化出更加丰富多样的主题与特色。

\section{5 街区保全型社区营造: 保护制度演进的幕后推手}

通过对日本历史风貌保护制度6个演进阶段的梳理（图1）皇可以观 察到, 20 世纪70年代地方分权型社会的到来是该进程中的一个重要转 折点。由于国家的行政体系从上意下达式的中央集权型管理模式转变 为由地方政府自主经营, 参与、分权等民主概念开始被地方社会所熟 知并接受, 公众参与街区保全型社区营造随之诞生。社区营造的概念 是相对于城市规划制度而言的, 社区最重要的精神是地方社会一致认 同的价值观和生活方式, 这种精神观念是从非官方、非专业的民间立 场发展而来的。街区保全型社区营造从广域上的街区保护出发, 以公 众参与和官民共治的形式推动了传建制度的产生。从这个意义上讲, 日本历史风貌保护制度的演进过程就是街区保全型社区营造产生和发 展的过程。接下来, 本文将就一个具体案例讨论保护制度演进过程中 街区保全型社区营造实现的途径。 same year, the Fourth Amendment of the Act on Protection of Cultural Properties was issued, according to which modern structures of high cultural significance were listed in the protection inventory. This was a remedial act which expanded the range of the protection for traditional quality against the drawbacks caused by the previous designated institution, further towards a diverse, flexible comprehensive conservation ${ }^{[11]}$. After Japan's economic collapse in 1990s, under the background of a nationwide reflection on the radical years, a conservation guideline was raised which laid stress on that urban growth should be developed stage by stage and the conservation of historical, cultural, and natural environment should be carefully considered in urban construction and community building.

The Act on Protection of Cultural Properties was revised again in 2004. The Fifth Amendment included the cultural landscapes created by the interaction between human and nature into the protection range of traditional quality ${ }^{[12]}$. In the same year, Landscape Law was introduced to ensure the conservation of natural scenery, diverse lifestyles, and local identity, empowering city- or town-level governments to establish specific, autonomous conservation institutions of historic quality.

\subsection{Neighborhood Conservation-Based Community Building:} The Booster in the Evolution of Conservation Institution of Historic Quality

Based on the review on the six evolving stages of the conservation institution of historic quality (Fig. 1) ${ }^{[9]}$, it is found that the empowerment from the state government to local authority in the 1970s was the turning point in the process. The decentralization helped change people's mind, making them to be aware of and to accept public engagement and autonomy. Community building is to challenge the conventional urban planning system. The essence of community spirit is about local identity and lifestyle which are stemmed from informal traditions. The concept of neighborhood conservation-based community building was generated to realize neighborhood protection in a broader way, encouraging the establishment of protection institution of traditional buildings through public engagement and authority-citizen joint-governance. In this sense, Japan's protection institution of historic quality can be understood as the exact process of the development of neighborhood conservation-based community building. This paper will make a further introduction on the practice of neighborhood conservation-based community building through a case study in Fukushima of Yame City. 


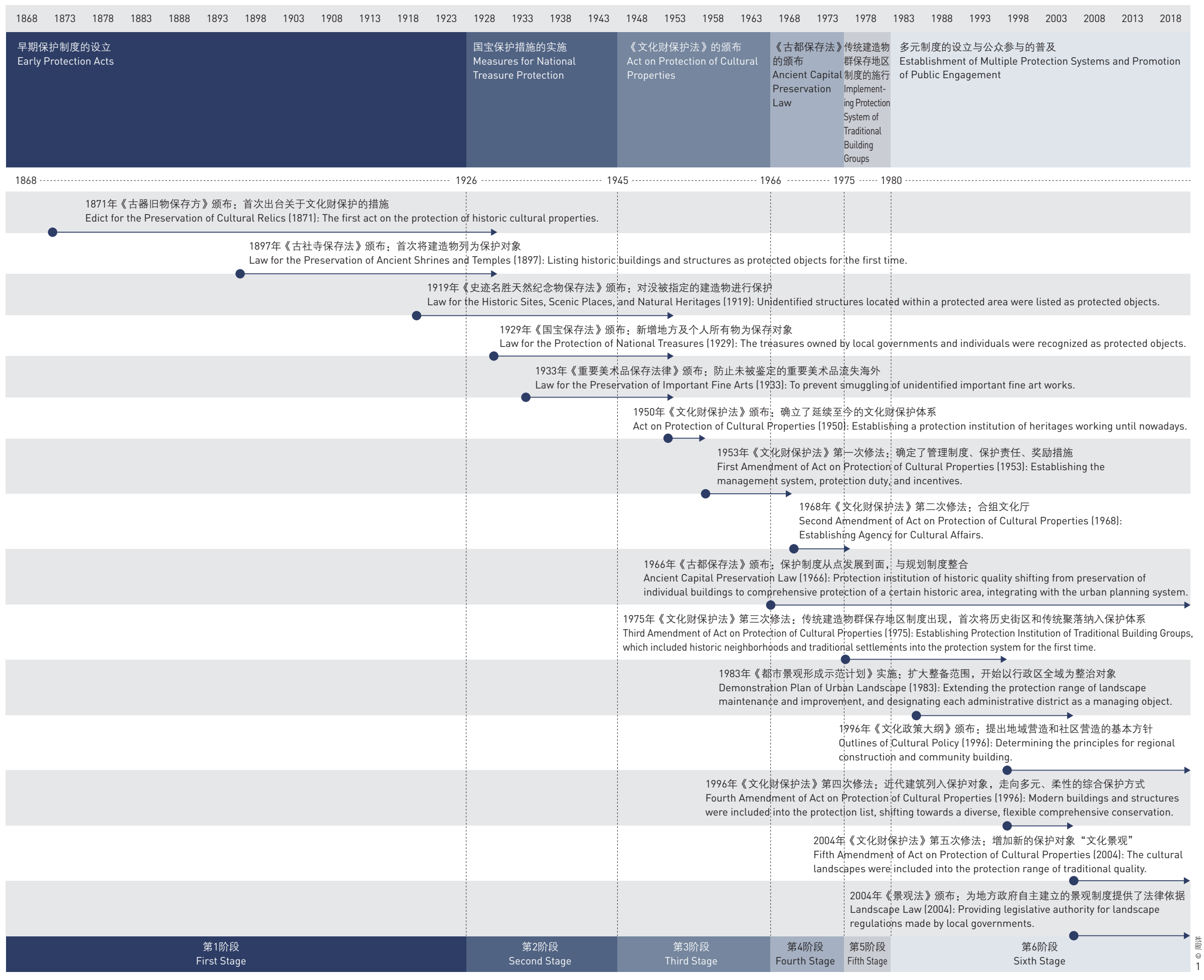

日本历史环境保护制度 的发展与演变

2.八女市福岛地区城下 町复原图和地域构造 图 ( 来源: 参考文献 [18] )
Evolution of protection system of historic quality in Japan and the map of main structures in Fukushima, Yame [Source: Ref. [18]]. 


\section{3 街区保全型社区营造的实践路径：以八女市福岛地区为例}

\section{1 营造运动的发起}

位于日本福冈县南部的八女市是一个三面环山的小城, 占地面积 约 $482 \mathrm{~km}^{2}$, 人口约 6.9 万。位于市中心的福岛地区至今仍保留着江户时 代建造的传统町家 (图2), 地区周边则坐落着自弥生时代 (约公元前 300 年至公元 250 年）就已存在的乡土聚落。

1991年，八女市遭受超强台风侵袭，借由街区重建的契机，福岛 地区于1993年开始探索街区景观功能整备方案，并于同年制定了《传 统街区景观整备导则》 ${ }^{\mathbb{1}}$ 。该导则的引人有助于居民根据其自主协定进 行街区景观修缮。虽然日本政府于1975年建立的传建制度能够有效保 护传统街区的历史风貌，但是该制度规定居民只能按照政府要求的样 式进行修缮，没有选择和协议的权力。条件如此苛刻的景观修缮制度 无疑使福岛居民颇为反感，因此在营造运行的初始阶段并未能引进该 项制度。1994年，八女市财政科发起 “街区景观整备委员会”，同时 与当地居民缔结了《社区营造协定》, 并确定了社区营造实施的范围 （图3）。1995年, 为了有效推行协定的相关内容, 福岛地区的町内会 会长和居民代表共同成立了“传统街区协定者营运委员会”（以下简
3 Practices of Neighborhood Conservation-Based Community Building: A Case Study in Fukushima of Yame

\subsection{Background of the Community Building in Fukushima}

Yame, a small city located in the south of Fukuoka

Prefecture, Japan, covers an area of $482 \mathrm{~km}^{2}$, with a population of about 69,000. The Fukushima area in the city center remains traditional Japanese residential structures built in the Edo Period (Fig. 2), and there are well-preserved vernacular settlements formed since the Yayoi period (from about $300 \mathrm{BC}$ to $250 \mathrm{AD}$ ) in the hilly surroundings.

Yame was once damagingly attacked by typhoon in 1991 . Two years later, as part of the rebuild project, the Guidelines for Traditional Streetscape Maintenance and Improvement ${ }^{1}$ was developed for Fukushima area to help residents repair and improve the neighborhood landscapes based on their common agreements. The Japanese government established the protection institution of traditional buildings in 1975 which greatly contributed to the protection of Japan's traditional quality, but people had only been allowed to repair their houses in compliance with what the government specified. Unsurprisingly, due to local residents' resistance, the regulation was failed to implement in Fukushima area at first. In 1994, the Finance Bureau of Yame constituted the Committee of Landscape Maintenance and Improvement in Historic Neighborhood, and made the Agreement on Community Building with the locals and designated the implementation areas (Fig. 3). In 1995, Executive Committee of Historic Neighborhood Conservation

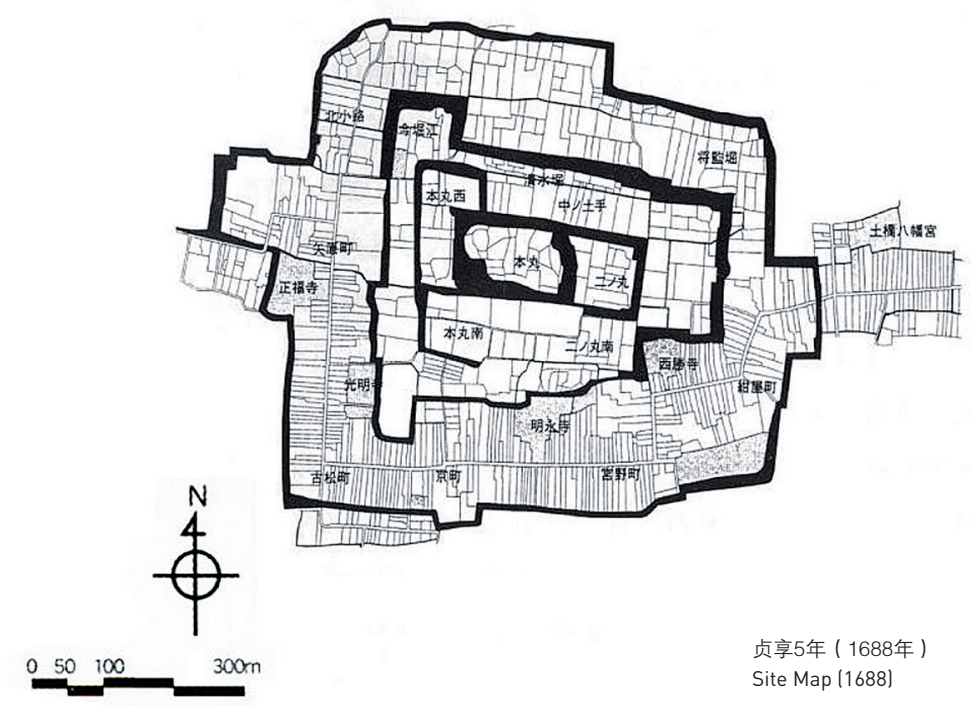

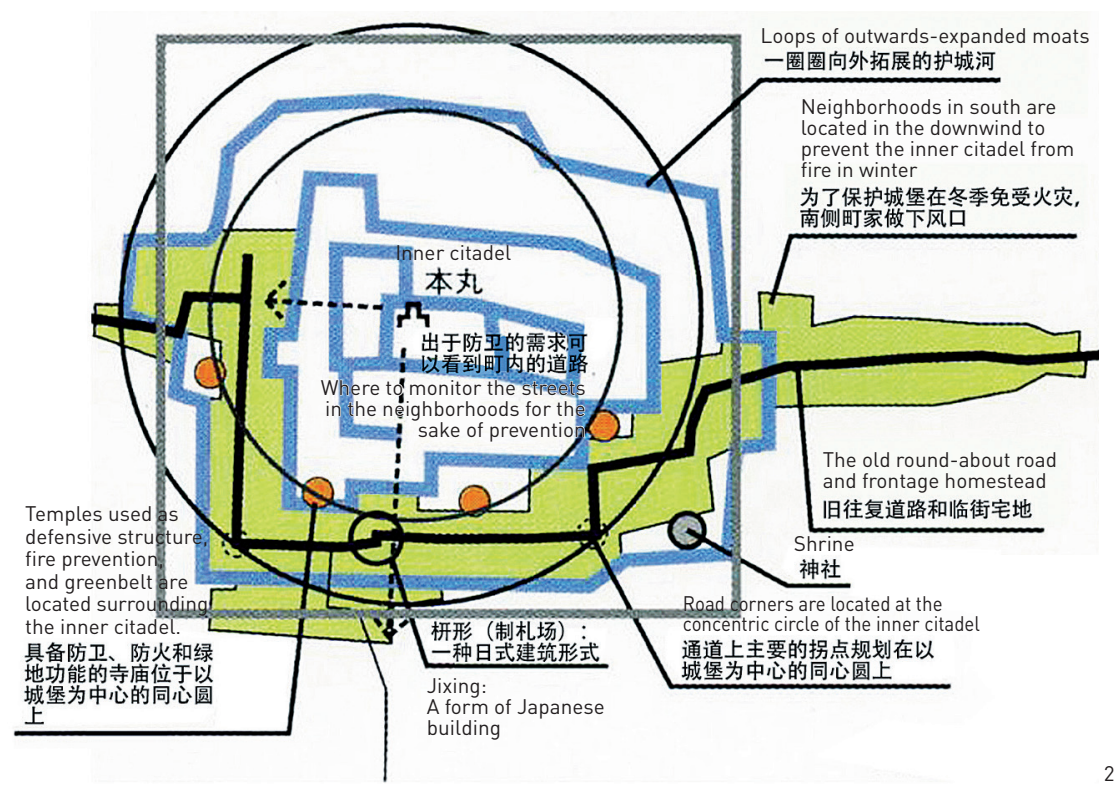


称 “协定委员会” ），开始落实街区整备工作。值得注意的是，由于 八女市财政科有意将协定委员会纳人组织化的管理体系, 该机构通过 向街区环境整备计划支付运营费用和指派工作人员在协定委员会中担 任重要职务, 希望以幕后推手的形式为居民开展社区营造提供指导 ${ }^{[13]}$ 。 协定委员会这种半官方半民间的组织性质, 使其不仅能够在运动初期 从官方的视角把控营造方向, 从而较易得到行政部门的帮助; 同时又 能够从民间的立场阐述街区保全对居民的益处, 有助于获得当地居民 的理解和支持。这一柔性对策在提高居民关于保全的必要性认识的同 时, 也为日后引人传建制度带来可能。

\section{2 营造目标的建立}

由于缺乏专业的建筑指导, 福岛地区的景观修缮工作出现了诸多 问题。例如, 协定方案将 “模仿传统建筑” 或 “与传统建筑相协调的 建筑” 列为补助对象, 但在实际操作过程中, 即使是那些并未尊重八
(ECHNC) was established whose board members including the heads of community associations and local residents in Fukushima to promote the landscape maintenance and improvement. Noteworthily, by positioning ECHNC as a part of the administrative system of the city, the Finance Bureau of Yame acted as the driving force behind the promotion who financed the landscape maintenance and improvement and guided the locals to protect and improve their neighborhoods ${ }^{[13]}$. The semi-official nature of ECHNC made itself capable of leading the improvement work in a right way and gaining supports from government; meanwhile, as a quasi-civil organization, ECHNC represented local people's interests; therefore, it worked as a conciliated agency, enhancing residents' awareness of neighborhood conservation and making establishing the protection institution of traditional building in future a possibility.

3.2 The Objectives of the Community Building in Fukushima

Lacking necessary guidance and help from architectural professionals, many problems emerged in the process of landscape restoration in Fukushima. For example, according to the Agreement on Community Building, the owners of those buildings and structures in a traditional Japanese style or being

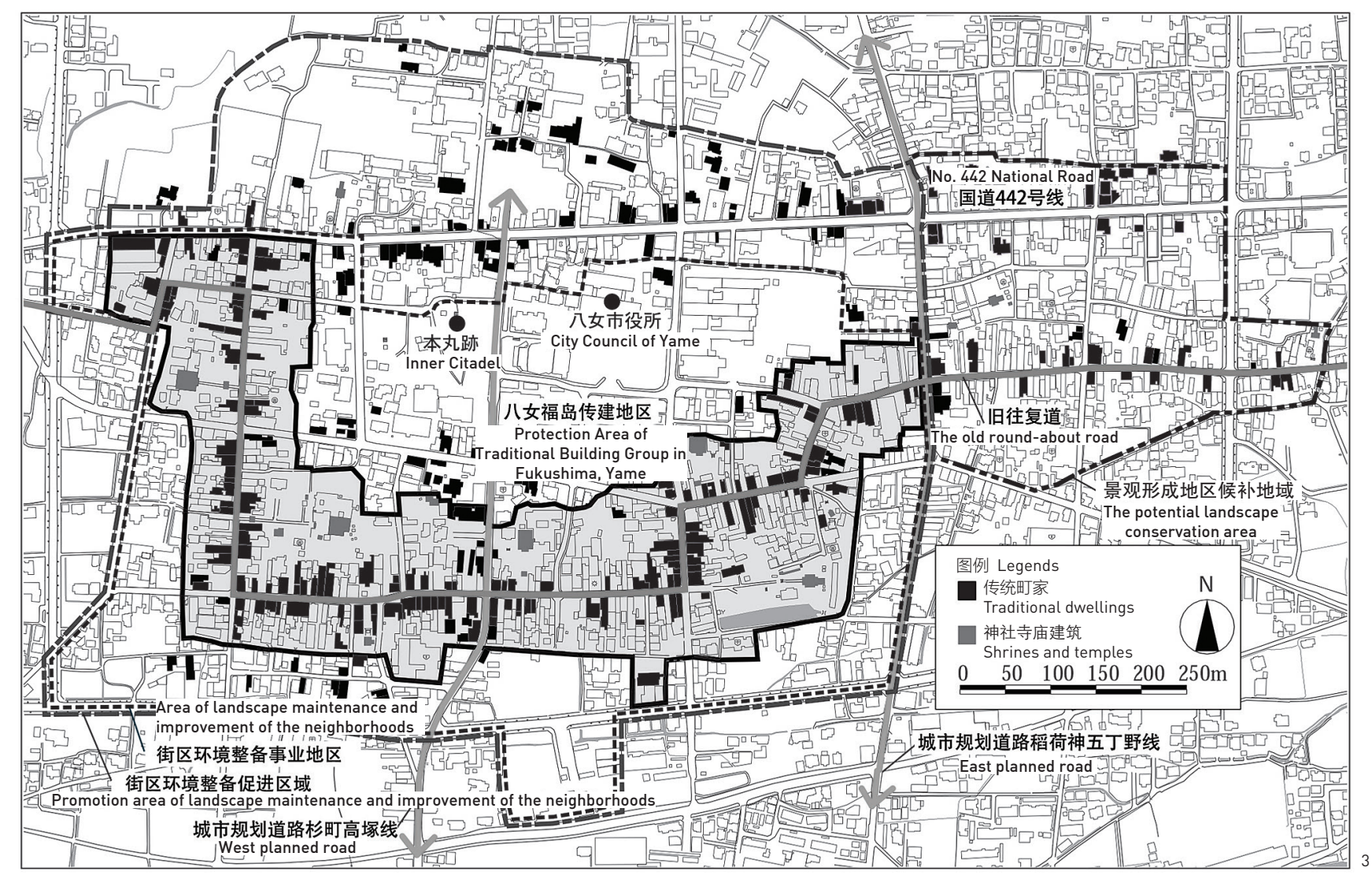
[14] )

八女市福岛地区传统建 造物群保存地区传统建 筑样式

3. The boundary of community building and the traditional private dwellings in Fukushima, Yame (Source: Ref. [14]]. Typical traditional buildings in the protection area of traditional building group
Yame. 

是指将保护区内的传统 建筑完全按照原有风貌 和历史特征进行严格修 和历史特征进行严格修 复; “修景”则是对保 改造, 使其尽可能地与 传统建筑保持统一或协 调的风格。

(2) In Japan, the restoration of traditional building must be in strict must be in strict
accordance with the original appearance and historic features in the protected neighborhoods; the restoration of the restoration of streetscape refers the renewals on ordinary building and structures in the protected areas to make them in a traditional Japanese architectural style, or being coordinate with the traditional weilding in the histo neighborhoods.
女市福岛地区传统的建筑样式，只要外墙是白灰泥或将木板纵向贴上 的建筑就能获批补助 ${ }^{[14]}$, 这无疑使《社区营造协定》的合理性遭到质 疑。针对这样的问题，协定委员会在八女市财政科和专家的帮助下， 于1998年发布了旨在体现社区营造目标的《街区修理与修景指

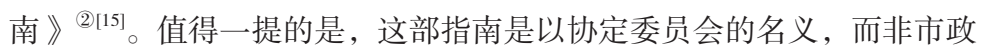
府或者教育机构的名义发行, 其目的在于向当地居民传达, 街区整备 与景观修缮是依照与居民之间的协定而推动的事业。指南的颁布使居 民在短时间内了解到社区营造所带来的禆益, 同时协定委员会也意识 到成立由建筑技术人员组成的专业研究会的必要性, 遂于 2000 年, 由 当地建筑师联合发起并成立了 “街区设计研究会”。该研究会的出现 使得八女市福岛地区按照传统建筑样式 (图4) 进行景观修缮的目标 最终实现。

\section{3 营造实践的开展}

如前文所述，虽然当地居民对传建制度持反对态度，但由于街区 引人的《传统街区景观整备导则》只有 20 年的有效期, 这就使得八女 市政府不得不重新考虑采纳无期限限制的传建制度。于是在2000年, 协定委员会与建筑院校的教授和福岛地方建筑师共同发起了“传建促 进委员会”，同时制定了《传建保存条例》。

委员会在对传建保存地区进行讨论时遇到的最大难题是两条贯穿 传建保存区的既有城市规划道路（图3）：如果按照原计划拓宽道路, 不仅会毁坏部分传统民宅, 也会切断两侧传统街区间的联系; 加之东 侧的规划道路为交通量较大的主干道, 道路改造因此颇具难度。最终 在促进委员会和行政部门的多次协商下，以取消西侧规划道路同时缩 小东侧保存地区范围的折中方式进行提案 ${ }^{[16]}$ 。

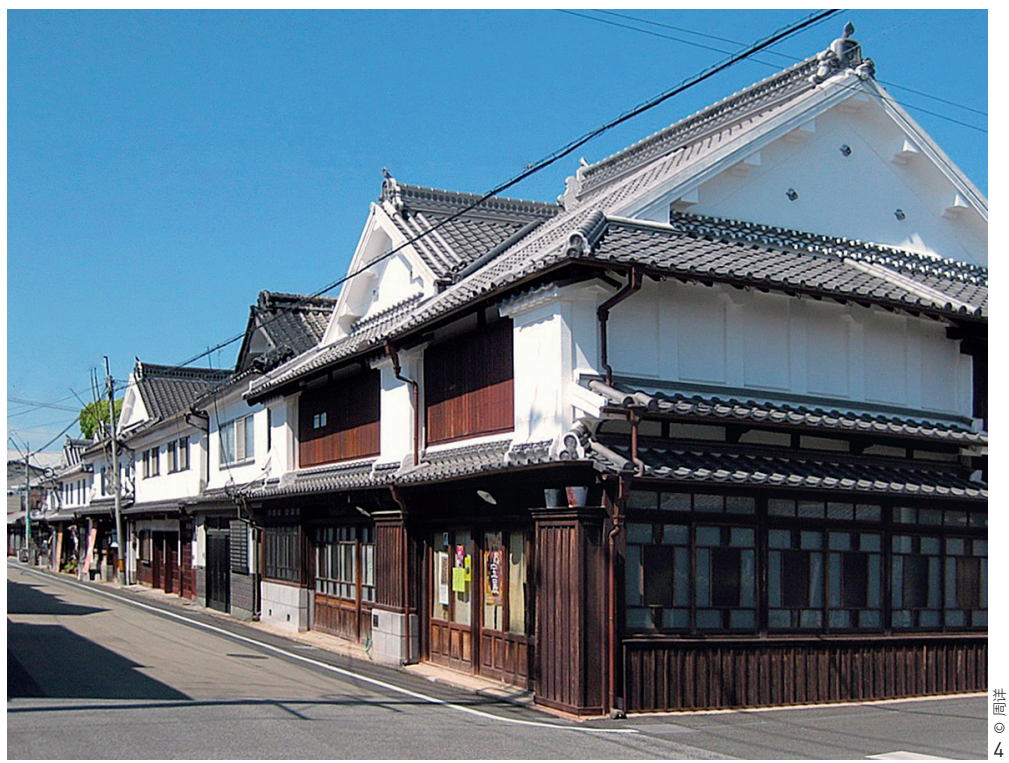

coordinate with the traditional architectural style could receive a construction subsidy. However, the real fact was that the owners whose houses were not in a traditional Japanese style - worse, who only built white walls or wood-cladding facades - were included in the subsidy-receiver list ${ }^{[14]}$, resulting in that the legitimacy of the Agreement on Community Building was strongly questioned. With the support from Finance Bureau of Yame and the help from architectural experts, the Guidelines on the Restoration and Improvement of Traditional Building and Streetscape in Historic Neighborhood ${ }^{2}$ was published in 1998, which specified detailed objectives of the community building in Fukushima ${ }^{[15]}$. It is worth mentioning that the Guidelines was published in the name of ECHNC, rather than other municipal agencies or public educational institutions, further suggesting that the promotion of neighborhood and landscape improvement was based on the Agreement on Community Building. The introduction of the Guidelines made it possible for the residents to easily understand the benefits that the community building could bring. ECHNC also realized the importance and necessity to establish a steering committee on architectural restoration, and established the Neighborhood Design Research Committee with local architects in 2000. The Research Committee greatly contributed to the success of streetscape restoration of historic neighborhood in Fukushima (Fig. 4).

\subsection{The Practice of the Community Building in Fukushima}

Because the validity of the Guidelines for Traditional

Streetscape Maintenance and Improvement was twenty years since its enforcement in 1993, the Yame government had to consider the reintroduction of the Protection Institution of Traditional Buildings which was of indefinite validity yet once stirred the local residents' resistance. In 2000, co-organized with architectural scholars and Fukushima-based architects, ECHNC established the Promotion Committee of Traditional Building Groups and developed the Regulations on Preservation of Traditional Buildings.

The biggest challenge encountered in the design process of the preservation of traditional building groups was to redesign the two main roads throughout the project area in the previous urban planning (Fig. 3). According to the proposal, the two roads were supposed to be broadened yet at the cost of damaging traditional buildings and cutting the connection between neighborhoods. In addition, the road on the east side was planned as a traffic backbone to the city of Yame that required an extremely careful redesign. Through negotiation with the authorities, the Promotion Committee finally developed a compromising proposal in which the western road was removed and the preservation area in the east was reduced ${ }^{[16]}$. 
在这个过程中, 参与和赋权是营造实践得以开展的重要动因, 正 是这些民主举措使市民成为了社区营造的主体，且使运营机制得到了 行政上的保障。

\section{4 营造范围的拓宽}

社区营造的基本诉求是保护街区整体的传统生活方式。由于保 存地区以外的民宅无法获批补助, 导致这部分地区的居民对这种差别 化对待的保护方式产生了质疑。因此促进委员会在进行提案时也开始 讨论保留着传统民宅但被排除在传建地区范围以外的东侧地区的问 题, 最终提出以制定《景观形成条例》的方式设置 “景观形成地区制 度” , 并将有益于地区传统风貌维护、应受保护的建筑物和景观环境 指定为 “景观形成物”。该制度最大的特点在于可推动景观形成地区 施行与传建地区相一致的补助标准。同时, 促进委员会考虑将该制度 应用到传建地区周围的缓冲地带, 以进行更大范围的风貌保护。而对 于传建地区以外遍布田园景观的乡村地带, 促进委员会则将之视为

“文化景观”的组成部分，也纳人到保护范畴。2001年，八女市政府 最终制定了包括《景观形成条例》和《传建保存条例》在内的《八女 市文化景观条例》。该条例的出台使原本只有福岛地区的居民才能享 受的整备补助计划也可以在其他景观形成地区推广[17]。对于行政部门而 言, 该条例不但有效地缓和了福岛地区以外的居民长期被差别对待的 不满情绪, 也推广了文化景观的概念。2002年, 八女市福岛地区被日 本政府指定为日本第61个重要传建地区。

\section{5 日本社区营造的未来转型}

在日本, 以当地居民和社区组织为主导, 以保护街区环境为目标 的社区营造是历史城镇发展的重要途径。八女市福岛地区成为在社区 营造过程中恰当构筑官民合作体系的成功案例（图5)。当具有战略眼 光和技术支援的行政部门与最了解地域文化和传统特性的在地居民联 合起来, 无限的创造力和多元的价值取向就被激发出来, 地方社会的 整体运营也被赋子了既充满个性又极为丰富的文化景观内涵。
It can be concluded that the practice of community building in Fukushima was driven by initiatives of public engagement and empowerment, which respected the citizens as principal participants and ensured the operation system with the administrative strength.

\subsection{The Expansion of the Area of Community Building}

The primary goal of community building is to protect the traditional lifestyle of historic neighborhood as a whole. However, the protection institution was criticized for the partial and unfair policies according to which the people who lived outside the preservation areas could not be granted the construction subsidy. Thus, the Promotion Committee began to reconsider the way to protect the traditional buildings located outside the east preservation area. As a result, the Regulations on Landscape Conservation was introduced to protect the structures and landscapes which were beneficial to the historic quality maintenance. The Regulations also applied the same subsidy standard in all the qualified area. At the same time, the Promotion Committee attempted to apply this system in the buffer areas surrounding the traditional building groups in order to form a larger protection territory. Furthermore, as part of the cultural landscape in Yame, the rural areas with pastoral landscape were also included in the protection inventory. In 2001, through the combination of the Regulations on Landscape Conservation and the Regulations on Preservation of Traditional Buildings, the Yame Cultural Landscape Regulations was issued with a purpose of promoting the institution of landscape maintenance and improvement of historic neighborhood in the whole city $\operatorname{area}^{[17]}$. The introduction of this Regulations conciliated the citizens who lived outside the Fukushima area while enhancing people's awareness of cultural landscape. Through all the efforts, Fukushima area in Yame was granted as Japan's 61st Important Area of Traditional Building Groups.

\subsection{Future Vision of Community Building in Japan}

Driven by local residents and organizations, Japan's neighborhood conservation-based community building is a main approach to the development of historic towns. The Fukushima case demonstrates how the official-civil-partnership worked in promoting local community building (Fig. 5): with the strategic vision and technical support from administrative system and the knowledge from native inhabitants, dynamic creativity and diverse methods were generated, giving the operational system of local society a dimension of enriched cultural landscape. 


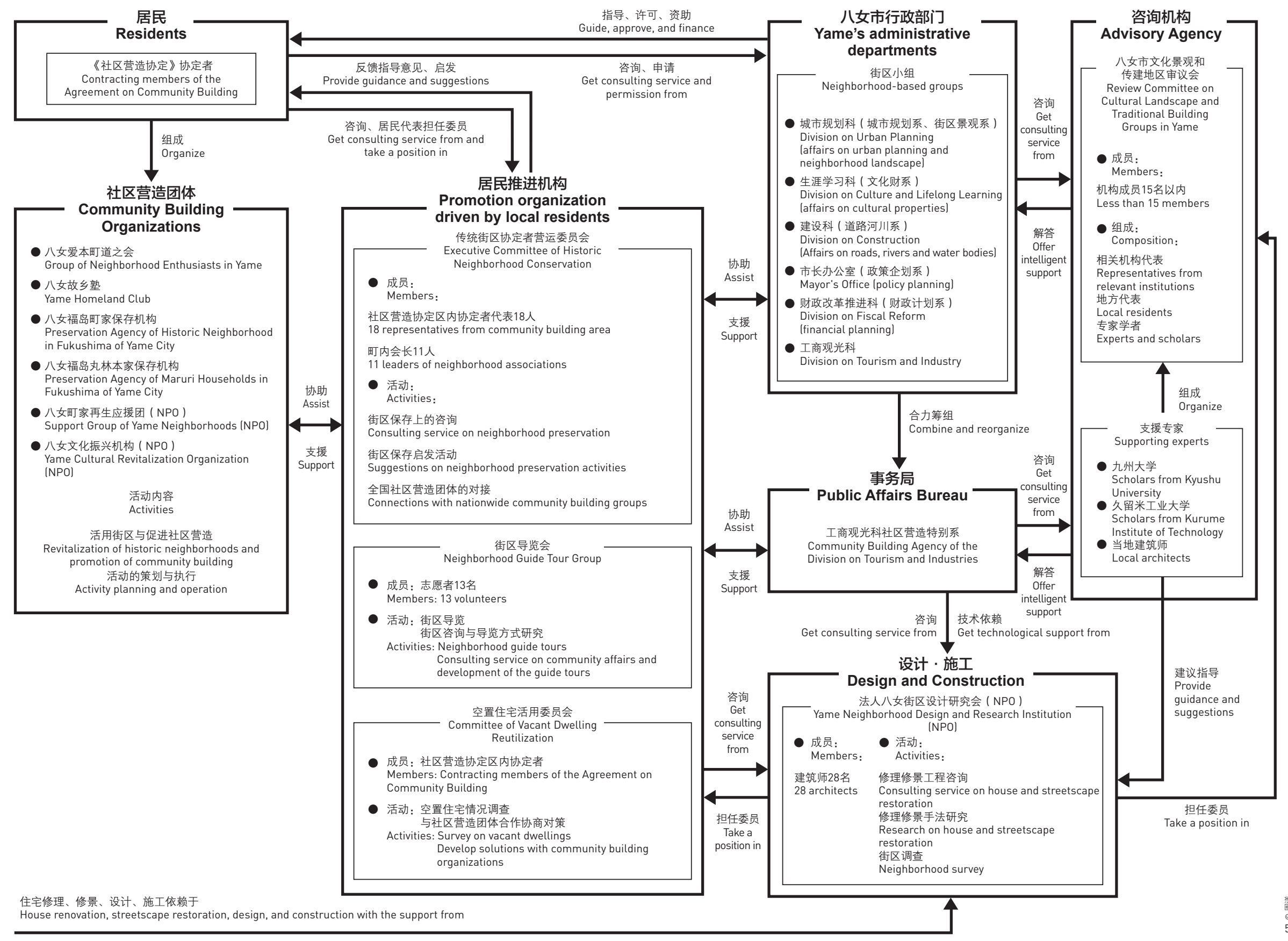

5.八女市福岛地区社区营造推动体制

5. Promotion system of community building in Fukushima, Yame. 


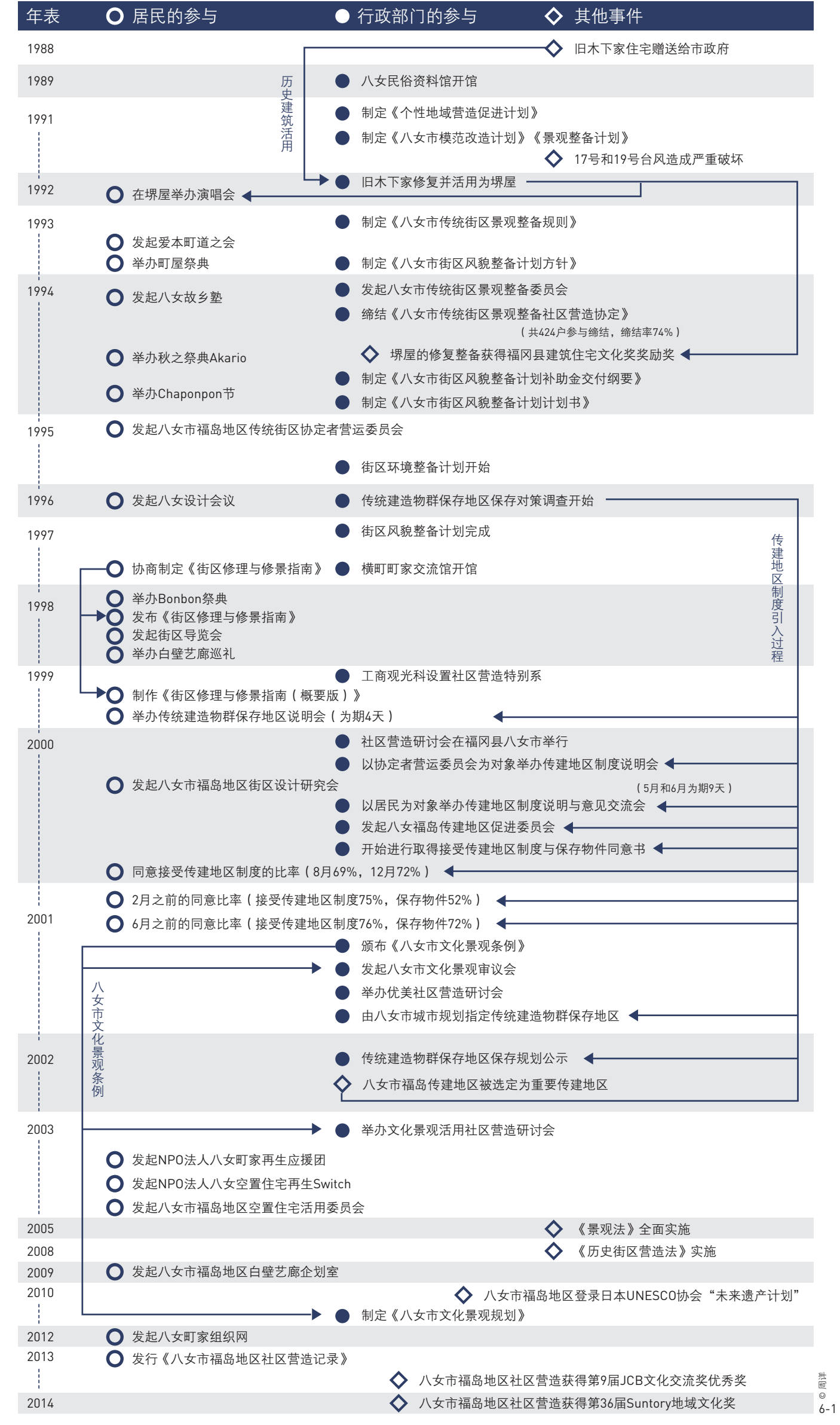

2010年末，《八女市文化景观规划》公布。为了提升居民的文化 景观意识，该规划提出采用政府和民间资本合作的PPP模式推动景观政 策的发展 ${ }^{[18]}$, 重点强调要在城镇的动态发展中, 维持和继承八女市文 化景观的特性; 同时，规划提出了景观型社区营造和社会循环型社区 营造的设想，提倡用景观整备的方式带动地域社会的整体复兴，从而 增加社会活力, 以此来应对日本目前少子高龄化的社会现象。由此可 知，当街区保全型社区营造完成既定目标之后，景观型与社会循环型 社区营造将成为当地接下来的发展方向。

从灾后社区重建，到对地方传统建筑的认识，再到对地域整体文 化景观的认知，八女市福岛地区的营造事业成为街区保全型社区营造 演进过程的一个缩影（图6）。在此过程中, 街区保全的视野是当地各 项保护制度引入和发展的内在动因。

\section{4 结论与讨论: 街区保全型社区营造对中国历史街区保护和开 发的启示意义}

\section{1 社会效益与经济效益的权衡}

从对城市问题的反思，到对街区特色进行主题式的发掘，再到地 域社会的整体运营，街区保全型社区营造走出一条从微观的社区事务 到宏观的地域事业的演进之路。目前，八女市福岛地区的社区营造正 朝向地域社会整体运营的成熟阶段发展。当社区营造成熟运作以后, 社区活力的提升必然导致街区地价的溢出。此时管控机制就变得十分 重要，因为营造事业一旦成功，若不加以有效管理，往往会陷人投机 经营的模式，届时社区会不断迎合旅游观光的需求而发展，随着低格 调商业化经营手法的渗人，社区会丧失最初的吸引力，从而陷人萧条 的容境；而外来资金投人也很容易在得到短期收益以后，迅速转移到 新的商机上。这些投机行为若不加以管控，无疑会给地方社会带来沉 重打击。

在日本，街区保全型社区营造大多被政府与民间团体视为历史 街区的再生政策而共同构建，这类社区的保护异于一般的城市开发项 目，更侧重项目的社会意义和环境效益。因此，通过行政部门与社区 营造组织的合作，回到社区营造构筑地方福祉的原则上，推动地方营 运体制的整备工作十分必要, 这也是中国当下开展社区营造需要着重 思考的问题。 


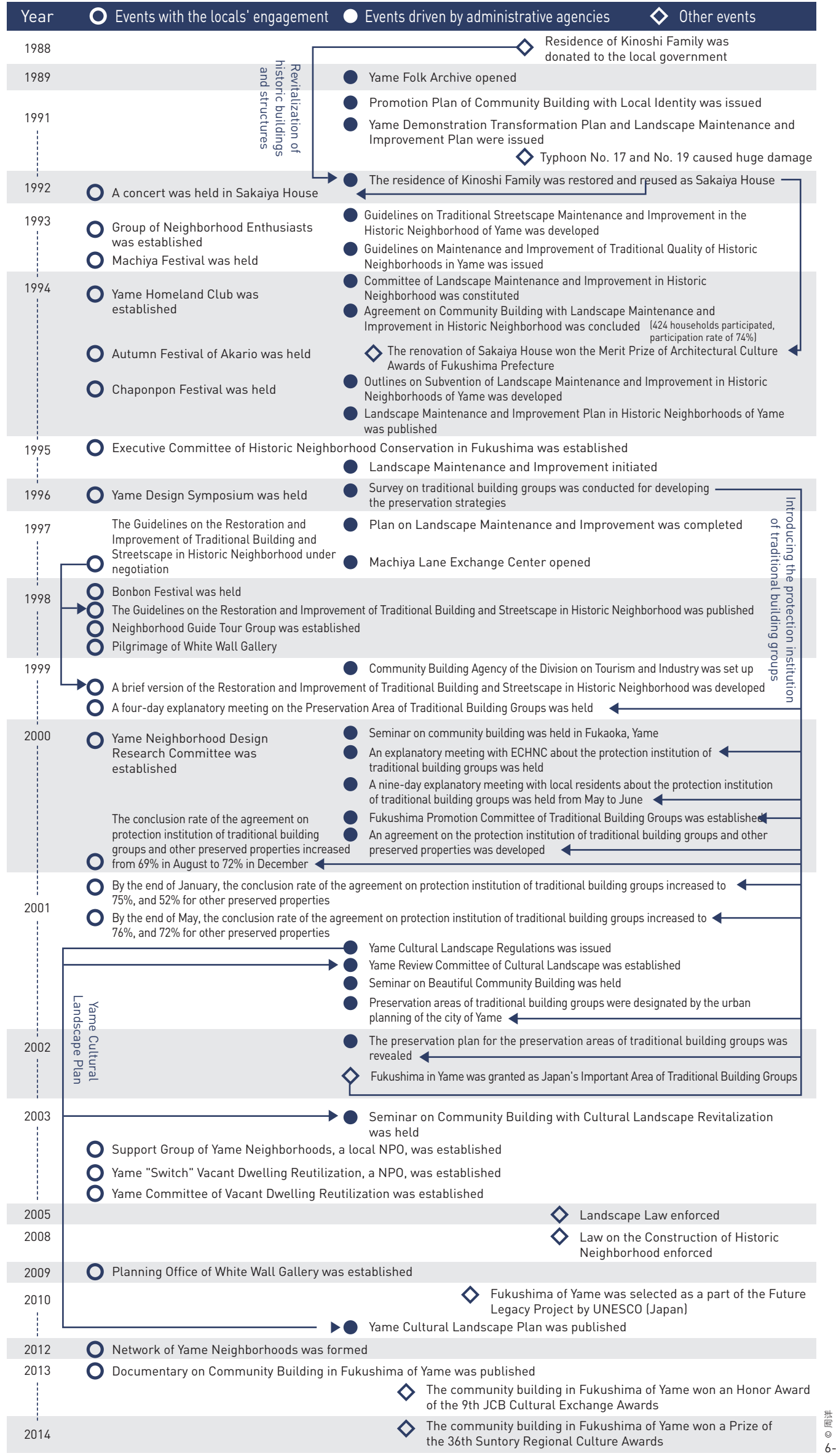

At the end of 2010, the Yame Cultural Landscape Plan was published, in which a public-private-partnership was introduced in the promotion of cultural landscape conservation ${ }^{[18]}$, especially to maintain the quality of the cultural landscape of Yame in the context of changing urban growth. In the Plan, a future vision about community building with landscape conservation and social sustainability was also proposed, facilitating an overall revitalization of local community through landscape maintenance and improvement in order to respond to the current situation of aging population with fewer children in Japan. It is implied that landscape conservation-based and socially sustainable community building is the new direction to the community building in Japan.

From post-disaster rebuilding to protection of traditional buildings and to conservation of cultural landscapes, the community building in Fukushima showed the whole evolution of neighborhood conservation-based community building (Fig. 6), in which neighborhood conservation has strategically been the motivation in the establishment and improvement of the whole protection institution.

\section{Summary and Discussion: The Lessons from the Neighborhood Conservation-Based Community Building in Japan for China's Protection and Development of Historic Neighborhoods}

\subsection{Social and Economic Benefits}

Currently, the neighborhood conservation-based community building in Fukushima shifts from dealing with local problems towards thinking the development of the regional society as a whole. Conceivably, the land price will be increased in the well-established communities which makes the establishment of a managing and monitoring system necessary. Otherwise the consequent profiteering economy would mislead the local development towards an unhealthy tourism-oriented growth, resulting in the loss of the identity of historic neighborhood, and, eventually, the economic depression, especially due to short-term opportunistic investments.

In Japan, most practices of neighborhood conservationbased community building are as part of the regeneration of historic neighborhoods co-driven by government and civil organizations, giving consideration to both social and environmental benefits. Therefore, it is necessary to promote the preparation of the local operating system to improve local well-being through the collaboration between administrative agencies and civil organizations. This is also the issue that China needs to focus on. 


\section{2 社区营造理念的共有}

历史街区的保护与开发是我国城市更新领域的热点话题。针对目 前“见物不见人” 的更新方式, 街区保全型社区营造这种尊重在地居民 切身感受和意愿的更新方式对于历史街区传统的社会关系和地缘社会支 撑体系的重构无疑具有重要意义。历史街区风貌的保护不仅与居民的日 常生活息息相关，还将促进发掘都市景观的历史文脉，在构建社区认同 与重塑居民主体性方面亦有积极意义。八女市福岛地区的经验表明, 街 区保全视角下的社区营造需要明确制定有别于城市规划体系的地方规 范，以建构当地居民共同遵守的行为框架。若是缺乏当地居民的理解与 支持, 无论怎样的社区规划都难以实施。由于许多地区缺乏对于风貌保 存的共识基础, 因此在起步阶段先行实施若干立竿见影的项目就显得至 关重要。

日本历史街区的保护从最初的单体保存, 发展到街区资源的活化 利用, 再延伸至关注在地居民的真实感受, 动态性的公众参与也在国际 社会获得越来越多的拥䂞。从公众参与的角度出发保护地域特色、重塑 街区形态是当前语境下中国历史街区保护和开发的应由之路。

\section{3 公众参与和社会永续}

简・雅各布斯曾经说过, 只有当城市是由每个人创造的时候，才 有能力为所有的人提供所需要的东西一一只有当前者作为前提条件时, 后者才能成立 ${ }^{[19]}$ 。随着居民保护意识和参与意识的增强, 各种以历史街 区风貌保护为宗旨的民间团体纷纷出现, 成为推动历史街区风貌保护工 作的一股重要的、可以因借的社会力量。目前中国社会正处于急剧变化 的时期, 这种趋势在社区事务中表现得尤为明显。随着参与、赋权等民 主概念逐渐被引人到中国的社区事务中来, 城市发展的经济学原理必将 让位于生活逻辑, 社区建设也将朝向更加民主、现代和人文的分权规划

\subsection{To Enhance Public Awareness of Community Building}

The protection and development of historic neighborhoods is a hot topic in the field of urban renewal. Challenging the conventional urban renewals simply focusing on physical reconstruction, neighborhood conservation-based community building is of great significance to the traditional social relations and the rebuilding of geo-social supporting system in the historic neighborhoods, through which local residents' willingness was fully respected. The protection of the traditional quality of historic neighborhoods not only is closely related to citizens' daily life, but also facilitates celebrating the historical context of urban landscape and contributes to building local community identity and residents' subjectivity. Fukushima's experience shows that in neighborhood conservation-based community building, the introduction of specific regulations and local norms was necessary, which helped form a protection framework that allowed everyone to comply. It has been repeatedly proven that community planning is hard to implement without the understanding and support from local residents. Considering that there was not a basic awareness and common agreement on the protection of traditional quality in many areas, it is important to implement a number of projects with obvious improvements in the initial stages.

Nowadays the protection of the historic neighborhood is far beyond single preservation of individual buildings and use of traditional resources; it focuses on how to reflect and meet the real needs of the inhabitants. The various, dynamic public engagement wins more and more recognition from all over the world. In China, conservation of local identity and reshaping neighborhood form is a must in the process of protection and development of historic neighborhoods.

\subsection{Public Engagement and Social Sustainability}

Jane Jacobs stated that "cities have the capability of providing something for everybody, only because, and only when, they are created by everybody ${ }^{[19]}$." With the enhancement of residents' awareness of conservation and engagement, various civil groups on conservation of historic neighborhood significantly contribute to the protection of historic quality in Japan. At present, Chinese society is in a period of rapid changes that is particularly evident in community affairs. With the introduction of the concepts such as public engagement and empowerment, people's well-being, rather than economic principles, will be prioritized in urban growth, while a more democratic, modern, and culture-based decentralization being the future direction in community building. The author believes 
方向转型。而街区保全型社区营造在动员社会力量参与社区事务方面 所形成的理念与机制，无疑对中国当下倡导的 “存量规划” 和 “参与 式规划”具有重要的借鉴意义。

“景观十年，风景百年，风土千年。”-2010年日本出版的一 本社区营造期刊的口号——总结了社区营造的核心精神 ${ }^{[20]}$ 。在日本，这 种本土化意味浓厚的社区营造并非一场有了成果便可以完结的政治运 动或社会事件, 而是需要世世代代不断耕耘才能持续推动的事业。从 这个意义上讲，社区营造不是结果，而是过程。LAF that the concepts and operational institutions applied in Japan's neighborhood conservation-based community building can be used for reference in China's efforts on inventory planning and participatory planning.

"The formation of a landscape takes a decade, a century for a scenery, and hundreds of years for a tradition." The propaganda of a Japanese periodical on community building, published in 2010, summed up the core spirit of community building exactly ${ }^{[20]}$. Japanese experience tells us that community building is not a political or social event to accomplish a single task; it is an ambitious vision which needs efforts of generations. In this sense, community building is never about the result, but the process. LAF

\section{REFERENCES}

[1] Nishimura, Y. (2004). What is Neighborhood ConservationBased Community Building. In Japan Architecture Society (Eds.), Neighborhood Conservation-Based Community Building in Japan (pp. 2-7). Tokyo: Maruzen Publishing Company.

[2] Passmore, J \& Hiromasa M (Trans) ] (1998) Man's Responsibility for Nature. Tokyo: Iwanami Shoten Publishers.

3] Sato, S., Atsugi, Y., \& Uchina, Y. (2017). Textbook of Community Building in Japan. Tokyo: Kashima Publishing Company.

[4] Zeng, X. Z. (2013). Community Building in Taiwan. Taipei: Sashay Culture Business Co., Ltd.

[5] Japanese Agency for Cultural Affairs. (1988). Culture and Cultural Administration of Japan. Tokyo: Gyosei Publishing Company.

[6] Cultural Property Protection Committee. (1960). History of Cultural Property Protection. Tokyo: Okusuji Publishing Company

[7] Shiina, S. (1977). Protection of Elite Cultural Property. Nagya New Japan Law Publishing Company.

[8] Japanese Agency for Cultural Affairs. (2017). Important Traditional Building Groups Conservation Area List. Tokyo: Japanese Agency for Cultural Affairs.
[9] Asano, S., \& Lin, M. Y. (2004). Neighborhood ConservationBased Community Building Developing with the Times. In Japan Architecture Society (Eds.), Neighborhood Conservation-Based Community Building in Japan (pp. 8-21) Tokyo: Maruzen Publishing Company.

[10] Koide, K. (1997). Institution and Evolution of Landscape Making. Landscape No.12 (pp. 90-94). Tokyo: Architectural Materials Research Company.

[11] Zhang, S. (2008). Introduction to Historical City Conservation Shanghai: Tongji University Press.

[12] Memorial Division of Cultural Affairs Bureau. (2005). Japanese Cultural Landscape: Research Report on Protection of Cultural Landscapes Related to Agriculture, Forestry and Fisheries Industry. Tokyo: Douseisha Publishing Company.

[13] Omori, Y. (2004). Yame: Community Building by Cultural Landscape Regulation. In Japan Architecture Society (Eds.), Neighborhood Conservation-Based Community Building in Japan (pp. 100-105). Tokyo: Maruzen Publishing Company.

[14] Omori, Y., Koguchi, A., \& Nishiyama, N. (2003). Conservation of Historical Townscape and Landscape by the Ordinance to Control Cultural Landscape: In Case of Yame-City, Fukushima Prefecture. Journal of the City Planning Institute of Japan,
38(3), 565-570.

[15] Executive Committee of Historic Neighborhood Conservation in Fukushima. (2008). Repair Manual of the Streetscape in Yame Fukushima District. Fukushima: Executive Committee of Historic Neighborhood Conservation in Fukushima.

[16] Yame Educational Committee. (1998). Survey Report on Conservation Measures for Traditional Buildings in Fukushima Yame. Kyushu: Kyushu Institute of Design, Historical Environment Laboratory and Urban Environment Laboratory

[17] Kitajima, T. (2002). Community Building to Make Use of Cultural Landscapes: Efforts by Craftmens in Yame. June Issue of Monthly Cultural Property, (465), 53-57.

[18] Kitajima, T. (2016). Development of Landscape Planning Utilizing Cultural Heritage: From the Site of Yame Fukushima Retrieved from: http://www.yame-machiya.info/wp-content/ uploads/2015/09/81c78e576db1ab64c5a6e992b0b67bb7.pd

[19] Jacobs, J. (1961). The Death and Life of Great American Cities. New York: Vintage Books.

[20] Committee of Kakurazaka Keyword No.2. (2010). Stylish Iki Community Building: Past, Present and Future. Tokyo Committee of Kakurazaka Keyword No.2. 